\title{
Banning Diesel Vehicles in London: Is 2040 Too Late?
}

\author{
Moayad Shammut ${ }^{1}$, Mengqiu Cao ${ }^{2,3, *} \mathbb{D}$, Yuerong Zhang ${ }^{3,4, *}$, Claire Papaix ${ }^{5}$, Yuqi Liu ${ }^{6}$ and \\ Xing $\mathrm{Gao}^{3}$ \\ 1 School of People, Environment and Planning, Massey University, Palmerston North 4442, New Zealand \\ School of Architecture and Cities, University of Westminster, London NW1 5LS, UK \\ Bartlett School of Planning, University College London, London WC1H 0NN, UK \\ Bartlett Centre for Advanced Spatial Analysis, University College London, London W1T 4TJ, UK \\ Department of Systems Management and Strategy, University of Greenwich, London SE10 9LS, UK \\ 6 Department of Social Work and Social Administration, The University of Hong Kong, \\ Hong Kong 999077, China \\ * Correspondence: m.cao@westminster.ac.uk or mengqiu.cao.13@ucl.ac.uk (M.C.); \\ yuerong.zhang.14@ucl.ac.uk (Y.Z.)
}

Received: 27 July 2019; Accepted: 6 September 2019; Published: 11 September 2019

\begin{abstract}
Air pollution contributes to 9400 deaths annually in London and diesel vehicles are considered a major source of lethal air pollutants. Consequently, the UK government announced its intention to ban diesel vehicles by 2040 to achieve a sustainable zero-carbon road transport system. Since no empirical studies have used a bottom-up approach to seek Londoners' views, it is therefore worth investigating the public opinion regarding this forthcoming ban. This paper aims to fill this research gap by taking London as a case study. A survey was designed, and fieldwork was conducted to distribute questionnaires to Londoners. Completed questionnaires were analysed using both quantitative and qualitative methods. The findings revealed that the majority of Londoners would be in favour of the ban if they were sufficiently exposed to the appropriate sources of information and were favourably disposed towards environmental protection measures. The results also showed that Londoners were more likely to switch to electric vehicles (EVs) if they were offered generous incentives and encouraged to use scrappage schemes. The present study makes a strong case for enforcing the ban well before 2040. The significance of this research is to provide clearer signals regarding the future of diesel vehicles, which in turn will strengthen the EV policy and uptake.
\end{abstract}

Keywords: low carbon technologies; low carbon transition; decarbonisation; zero carbon; air pollution; diesel ban; electric vehicles; transport policy; transport planning; London

\section{Introduction}

In recent years, European governments including the UK, have committed to addressing the adverse air pollution in their cities, by setting targets to decrease the carbon dioxide $\left(\mathrm{CO}_{2}\right)$ levels. Since then, the use of diesel vehicles has been incentivised and these are favoured over petrol vehicles in several European cities through the 1998 agreement between the European Automobile Manufacturers Association and the European Commission [1,2]. As a result, diesel vehicles now form a significantly increased share of the UK's licensed vehicle fleet. Since 1994, the proportion of diesel vehicles increased from $7 \%$ to about $40 \%$ in 2016, reaching a total of more than 12 million vehicles [3]. Although previous research has asserted that diesel vehicles are more $\mathrm{CO}_{2}$ efficient than petrol vehicles $[4,5]$, a very recent study revealed that diesel vehicles produce similar "real-world" $\mathrm{CO}_{2}$ emissions to petrol vehicles [6]. In the same study, the authors indicated that diesel vehicles have not demonstrated significant advantages over petrol vehicles in terms of $\mathrm{CO}_{2}$ emissions since 1995 in Europe. The policy of favouring diesel vehicles over petrol vehicles came at the cost of a considerable increase in air 
pollution in many cities, particularly in London, since diesel vehicles emit toxic pollutants such as nitrogen oxides $\left(\mathrm{NO}_{\mathrm{x}}\right)$ and particulate matter $(\mathrm{PM})$ [4], which are recognised as the most dangerous to the human health $[4,7]$. Thus, there is an urgent need to take action against the continuation of diesel vehicles.

Studies have shown that the transport sector emits the greatest amounts of greenhouse gas (GHG) emissions [8], whereby $95 \%$ of transport sector emissions are caused by the road transport [9]. In 2014, the road transport was responsible for $20 \%$ of all global $\mathrm{CO}_{2}$ emissions [10]. Although the scope of this paper focuses primarily on road transport emissions due to the scale of their contribution to London's air pollution [2], it is imperative to point out that there are other sources of air pollution that originate from within the transport sector such as aviation, rail, and maritime activities as well as other sectors including industrial and energy productions [2,11,12]. Therefore, it is argued that addressing the emissions produced by all of the aforementioned sources should be considered when developing policies for a sustainable zero-carbon transport system. Otherwise, failure to reverse the current trends in the transport emission concentrations will only exacerbate the situation and lead to further adverse consequences in the future.

London's air quality is considered the worst among European cities [13], and the UK has been threatened with legal action and fines if it fails to reduce its air pollution emissions in some cities including the capital [14]. As a result, successive governments and policymakers have tried to implement new policies to tackle air pollution in London but, regrettably, the crisis still prevails [15]. In addition, recent studies have revealed that the vast majority of Londoners $(82 \%)$ agreed that tackling air pollution must be a priority [16]. We therefore emphasise that effective new transport policies, tailored to the challenges that the capital faces, must be developed and introduced as a matter of urgency. This situation underpins the salience of this research paper.

In light of the current air pollution situation, the Mayor of London set a goal of achieving a zero-emission road transport by 2050 in the Mayor's Transport Strategy (MTS) [17], and the UK government is committed to lowering GHG emissions by $80 \%$ by 2050 through the 2008 Climate Change Act [11], as articulated in the Agenda 2030 for sustainable development [18]. It is argued that achieving this ambitious target can be attained by the decarbonisation of the transport sector [11]. Consequently, the UK government has announced its intention to ban the diesel and petrol vehicles by 2040 [19] in order to counteract air quality issues. The government justified the forthcoming ban by publishing reports [20] predicting that, by 2040, (1) high $\mathrm{NO}_{\mathrm{x}}$ levels in the UK will be one of the biggest environmental risks to people's health in terms of diabetes, asthma, bronchitis, lung cancer, and heart disease; and (2) air pollution in the UK is expected to destroy $50 \%$ of the plant life as well as $40 \%$ of the wildlife habitats. However, there is a continuing debate about whether banning diesel vehicles can provide the answer to tackling air pollution. On the one hand, some German politicians as well as car companies, are not in favour of the ban and feel that it is "excessive" [21,22]. On the other hand, transport and environmental experts $[7,15,23]$ realise the importance of the ban and have therefore made a strong case for policymakers to implement it as soon as possible. Recent research shows that banning diesel vehicles would have a significant impact on reducing the $\mathrm{NO}_{\mathrm{x}}$ and $\mathrm{PM}_{2.5}$ levels as well as improving the public health $[7,15]$.

Studies examining the public opinion concerning the ban are scarce. Previous literature paid much attention to interventions such as the creation of low emission zones (LEZs) [24-26], but the authors concurred that LEZs do not bring about the desired improvements in the local air pollution. One recent study investigated the potential economic and health benefits of banning diesel vehicles in Dublin [7], while others have attempted to predict the attitudes of UK drivers towards switching to electric vehicles (EVs) after the ban is introduced [20]. However, to the best of our knowledge, there have not been any empirical investigations, specifically using London as a case study, to gauge public opinion regarding the forthcoming ban on diesel vehicles in 2040. The public opinion with respect to any putative ban has yet to be fully explored. Furthermore, it is argued that the reluctance to implement the ban in the UK is a contributing factor to thwarting the early uptake of EVs as well as 
weakening the EV policy $[15,23]$. For this reason, our research is significant, as it investigates whether the ban can be implemented earlier than 2040. The outcome of this investigation will provide clearer signals regarding the future of diesel vehicles, which in turn will strengthen the EV policy and uptake.

We argue that addressing London's air pollution is fundamentally linked to three factors, namely: (1) A strong political will, which includes strategies and action plans on the city, national, and international levels; (2) the cultural paradigm, e.g., city branding. This comprises the practices and marketing of the city, which has a direct influence on sustainability and people's behaviours [27,28]; and (3) public participation. This paper takes into consideration the third factor, i.e., public participation, paying particular attention to the case study of London using a bottom-up approach.

This paper aims to fill the gap in the literature by establishing the public opinion and attitudes towards the ban. It also aims to investigate the rate at which the Mayor should implement the ban, and to explore what factors may influence the public acceptance of this policy. Although the forthcoming ban is intended to apply to both diesel and petrol vehicles, the core focus of this paper is on the diesel vehicles since they produce more toxic emissions that require further attention.

\section{Case Study, Data and Methods}

\subsection{Case Study Context}

London is the capital city of the UK with an approximate population of 10 million and this figure is expected to increase dramatically in the near future $[29,30]$. This rapid growth in the population has led to greater car use and ownership. In 2018, the number of private licensed cars in London had reached about 2.7 million [31], causing serious problems in terms of air quality and health. For instance, a study conducted in London reported that the number of deaths caused by the $\mathrm{NO}_{\mathrm{x}}$ and $\mathrm{PM}_{2.5}$ as being about 9400 per annum [32]. London is a popular destination for tourists from all over the world, and its air quality is considered the worst among British cities. Therefore, it was selected as a case study since it has an impact on millions of people.

The capital also possesses several characteristics that make it a suitable case for the investigation of banning diesel vehicles. First, it is regarded as a world leading city in the transport innovation and cutting-edge technology, as well as hosting a number of top-class researchers [33]. These factors enable innovative solutions and effective intervention measures to be generated [34,35]. Second, it is equipped with suitable tools to facilitate a shift away from diesel vehicles to more sustainable alternatives, as well as encouraging active travel via its sophisticated transport system [36,37]. Third, it offers a rich dataset in terms of modelled emissions for different air pollutants that is easily available for research purposes [38].

\subsection{Data and Methods}

Data used in this study were collected via a face-to-face survey which was distributed to Londoners by the fieldwork conducted from June to August 2018. We utilised a random sampling method [39], similar to the approach used by Cao [40], and Cao and Hickman [41-43]. Prior to each interview, participants were asked if they were permanent residents in London and aged 17 or over. The targeted sample comprised those aged 17 or over since it is only license holders from this cohort who are legally permitted to drive. Only those who fulfilled these requirements were accepted to participate in this study and complete the survey. With a view to filling the knowledge gap in the literature regarding public attitudes towards the forthcoming ban on the internal combustion engine (ICE) vehicles (i.e., diesel and petrol), the survey sought to: (1) Collect insightful information about the Londoners' level of awareness about the harm caused by diesel vehicle emissions; (2) establish their views and attitudes regarding the forthcoming ban; and (3) discover whether they would be willing to shift to EVs. We argue that undertaking these investigations using a bottom-up approach is important because driving diesel vehicles can be cost-effective. As such, diesel vehicles use slightly less fuel than petrol ones, which offer cheaper running costs. Thus, diesel vehicles might be perceived as a more 
convenient option. The survey was piloted to make sure that all the questions were clearly worded without ambiguity and to avoid problems related to a low response rate. It was checked by a small number of colleagues and peers $(n=18)$ at the University of Westminster and University College London. As a result, 139 valid responses were collected. The survey consisted of eleven multiple-choice questions, while the twelfth was an open question designed to allow respondents to provide more detailed comments, which have been used for qualitative analysis in this research.

This section outlines the survey questions that were distributed to Londoners: (1) Since poor air quality affects the quality of life referring to the state of wellbeing in terms of health, comfort, and happiness [44], the first survey question sought to ascertain the Londoners' levels of satisfaction in respect to air quality. This question sought to discover to what extent they agreed with the following statement: "I am satisfied with the air quality in London". (2) The second question in the survey aimed at identifying their level of awareness about the harm caused by diesel vehicles since it is argued that the level of awareness influences people's attitudes towards environmentally-friendly products [45]. (3) The next survey question was consequently designed to find out how Londoners would feel about purchasing a diesel vehicle having been informed about some of the health problems that diesel vehicles cause. Respondents were asked: "Emissions from diesel vehicles can cause premature deaths and many diseases such as asthma and lung cancer. Would you, as a consequence of the statement above, still be willing to purchase a diesel vehicle?" (4) In response to the UK government's announcement that ICE vehicles will be banned from the beginning of 2040, the fourth survey question involved a hypothetical scenario whereby respondents were invited to envisage that the government wished to enforce a ban on diesel vehicles from the start of 2019. The purpose of this survey question was to determine how quickly the Mayor of London should introduce the policy. (5) The fifth question in the survey asked respondents about the type of vehicle that they owned (i.e., diesel, petrol, EV, etc.) so as to provide an insight into the proportion of car users in addition to the vehicle types. (6) The sixth survey question was essential to gain insights into how the diesel and petrol car drivers would act if the government incentivises EVs or bans ICE vehicles completely. Therefore, only respondents who represent the car-driving cohort were required to complete this question. Respondents were asked to what extent they agreed with the following statement: "I would replace my diesel/petrol vehicle with an electric one." (7) The purpose of the seventh survey question was to ascertain whether participants had become sensitised towards the environment after they had been exposed to information about the potential harm caused by diesel vehicles. Respondents were asked about the kind of vehicle they would purchase if they were going to purchase one today. Lastly, the eighth, ninth, tenth, and eleventh questions in the survey sought to obtain information about the participants' characteristics in terms of gender, age, highest educational attainment, and main transport mode for work [41,43,46-48], all of which are presented in Table 1 below. The final survey question was an open question that asked respondents to provide any suggestions and recommendations on how to improve London's air quality in relation to the diesel vehicle emissions. 
Table 1. Sample characteristics.

\begin{tabular}{cccc}
\hline \multirow{2}{*}{ Gender } & & Frequency & Percentage \\
& Male & 76 & $55 \%$ \\
Age & Female & 63 & $45 \%$ \\
\hline \multirow{2}{*}{ Educational attainment } & $17-30$ years old & 73 & $52 \%$ \\
& Over 30 years old & 66 & $48 \%$ \\
\hline \multirow{2}{*}{ Vehicle ownership } & Secondary school or below & 1 & $1 \%$ \\
& Bachelor's degree & 67 & $48 \%$ \\
& Master's degree & 60 & $43 \%$ \\
& Doctoral degree & 11 & $8 \%$ \\
\hline \multirow{2}{*}{ Main transport mode for work } & Yes & 85 & $61 \%$ \\
& No & 54 & $39 \%$ \\
\hline \multirow{2}{*}{ Underground/Overground } & 20 & $14 \%$ \\
& Cycle & 25 & $18 \%$ \\
& Walk & 12 & $94 \%$ \\
& Others * & 5 & $4 \%$ \\
& Bus & 2 & $1 \%$ \\
\hline
\end{tabular}

* "Others" is comprised of working from home and/or not currently employed.

The present study utilises a non-parametric statistical testing method known as the Kruskal-Wallis $\mathrm{H}$ [49]. The test static, $\mathrm{H}$, is calculated by the following formula:

$$
H=\frac{12}{N(N-1)} \sum_{i=1}^{k} \frac{R_{i}^{2}}{n_{i}}-3(N+1)
$$

where:

$N$ : Total sample size

$K:$ Number of samples

$R_{i}$ : Sum of ranks in the $i$ th sample

$n_{i}$ : Size of the $i$ th sample.

The Kruskal-Wallis H Test (KWT) is a rank-based approach to the one-way ANOVA, which determines whether there are statistically significant differences between three or more groups for a dependent variable [50]. The KWT assumes that: (1) The sample population is drawn at random; (2) the observations of the samples are independent; and (3) the scale of measurement of the dependent variable should be at least ordinal [50]. This non-parametric statistical test has been used by many researchers [51-53], most commonly in behavioural sciences [54]. It is utilised in this study with the aim of gaining greater insight into the factors that may influence the public acceptance of the ban on diesel vehicles.

Perhaps a minor limitation of this method is that it indicates if there is a significant difference between groups but does not indicate which groups are different. Therefore, a qualitative analysis was conducted to overcome this limitation. In this paper, a mixture of quantitative and qualitative approaches is used [47]. The purpose of doing this is to minimise the disadvantages of each individual approach while maximising the benefits of both approaches combined [55].

\section{Results and Discussion}

\subsection{Air Quality Satisfaction}

The results show that the highest percentage of respondents (67\%) said they "disagree" with the following statement: "I am satisfied with the air quality in London". By contrast, only $22 \%$ of 
respondents stated that they "agree" with the statement, and approximately $12 \%$ said they "neither agree nor disagree".

For $67 \%$ of the sample population to be dissatisfied with London's air quality calls into question the validity of current policies aimed at reducing the air pollution. This result also indicates that further and quicker actions should be taken by the Mayor of London and the responsible authorities [56] as well as car industries [37], perhaps in conjunction with community-led initiatives. Nevertheless, experts argue that such initiatives led by the community alone are unlikely to have an impact in the long term as they have to be supported by governmental interventions [37].

To highlight the importance of exploring respondents' satisfaction with the air quality, a study conducted by MacKerron and Mourato [57] to assess the relationship between the air quality in London and Londoners' level of life satisfaction, found that air pollution and life satisfaction are significantly correlated, so that, as air pollution increases, Londoners' life satisfaction diminishes. This may suggest that air pollution not only affects people's health, but also their perceptions of life satisfaction. Policymakers are aware of the hazard generated by air pollution and it is therefore incumbent on them to act promptly.

The last survey question was an open question, which sought the respondents' in-depth views on air pollution in London. Regarding air quality satisfaction, one participant stated:

"Air quality is good in London." (male, 24).

Analysing the aforementioned respondent's statement, current studies show that this is not true for London as a whole. In fact, estimates show that air pollution in London contributed to 4267 deaths in 2008 [58] and that this figure had increased to about 9400 in 2015, according to Walton et al. [32]. Since London has consistently breached the legal limits of the $\mathrm{PM}_{10}$ levels, the UK has been threatened with legal action [14]. Poor air quality in London is also a motivating factor that underpins this research since the majority of Londoners stated that tackling air pollution should be prioritised [16]. However, it could be argued that the respondent referred to above may be living in a less polluted area, which they may regard as being, in their judgement, relatively cleaner or at least sufficiently clean. Perhaps it would make more sense if the respondent had stated that air quality is good in their particular area rather than proposing that what discretely applies to one area applies to London as a whole. Respondents who stated that they "neither agree nor disagree" with the statement above might also be living in areas of London that have relatively low levels of air pollution.

\subsection{Awareness Level of Diesel Vehicle Emissions}

From the analysis in Figure 1, about 33\% of the respondents considered themselves to be "moderately aware" of the harm caused by diesel vehicles, while a nearly equal number of respondents claimed they were "slightly aware" or "very aware" of the harm caused by diesel vehicles. Lastly, almost the same number of respondents said they were "not aware at all" as opposed to "extremely aware". This possibly indicates that the sample may have included a wide variety of respondents who come from different backgrounds. Only $9 \%$ of the respondents claimed to be "extremely aware", which suggests that they might belong to a group of experts, e.g., experienced transport planners and researchers with a doctoral or masters degree.

Additionally, $26 \%$ of the respondents were "very aware" of the harm caused by diesel vehicles. We might speculate that this percentage could include less experienced transport planners as well as researchers and students in related fields. Certainly, it is essential to determine the level of awareness among the population in order to understand how to proceed, and to plan for the next stages. For instance, if there is little awareness about the harm caused by diesel vehicles, then the next step to be taken is to put more efforts into prioritizing new policies aimed at increasing awareness. By contrast, if there is already a considerable level of awareness, then the next step would involve implementing new and more rigorous policies targeting air pollution such as the banning of diesel vehicles [2,7]. Indeed, those who are aware of the harm caused by diesel vehicles would already possess an appreciation of why the government might consider banning such vehicles. 


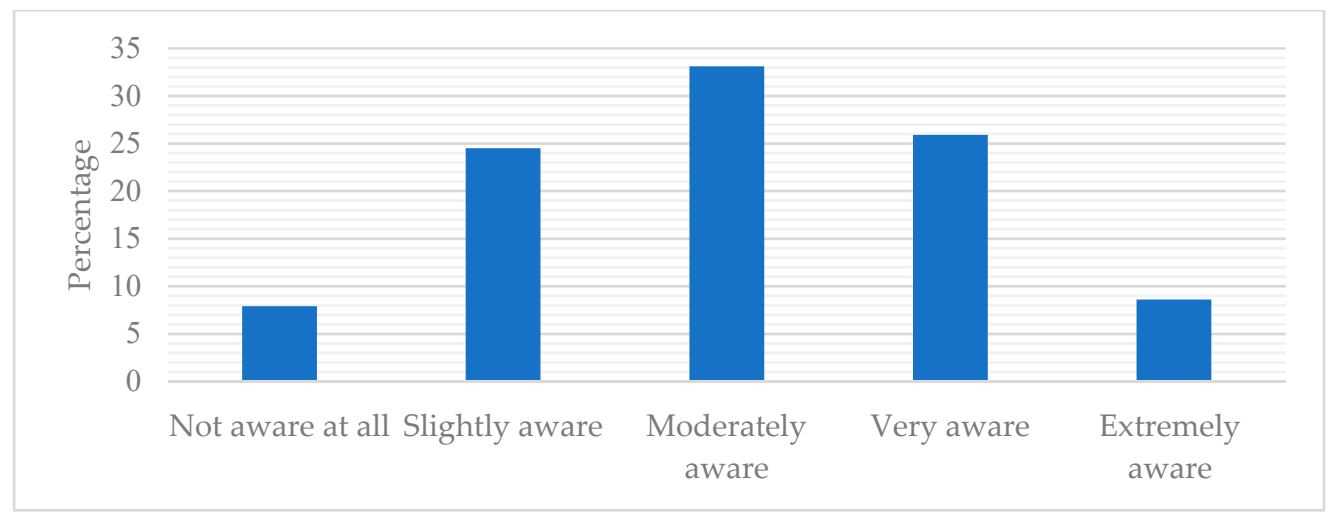

Figure 1. Awareness level of the harm caused by diesel vehicle emissions.

Levels of awareness could play a significant role in the shift away from diesel vehicles [56] and any move towards zero-emission vehicles, as stated in the MTS. This argument is also supported by the views of Londoners who completed the survey. In response to the last question, which invited respondents to offer their own recommendations for tackling air pollution in London, two respondents suggested the following:

"Have better knowledge on air pollution." (female, 23).

"To have a screen on the streets that displays real-time air pollution concentrations to make people more aware of the air pollution in the city." (female, 18).

Curtis and Headicar [59] found that raising the public awareness could play a substantial role in persuading people to switch from car usage to other forms of transport. Moreover, it is crucial to make people more aware of the fact that diesel vehicles emit toxic pollutants that are immensely harmful to health. Gaining their trust and confidence would undoubtedly help to implement new intervention measures to tackle air pollution effectively. Some scholars have argued [60] that educating the public about the possible harm caused by diesel vehicles would facilitate the more rapid implementation of the ban as well as facilitating a change in the current composition of vehicle fleets. It is further argued that people who possess awareness of environmental issues and concern about these tend to show positive attitudes towards EVs and other environmentally friendly products $[45,61]$.

\subsection{Information Provision}

Interestingly, the analysis shows that slightly over half of those surveyed (51\%) declared that they would not purchase a diesel vehicle after acknowledging the potential harm that they cause. However, a minority of the respondents (9\%) said that they would still purchase a diesel vehicle. Furthermore, about $40 \%$ of the respondents claimed that they might buy a diesel vehicle, which implies that changes in policies and regulations related to LEZs and banning diesel vehicles should be more flexible. For example, these could include tightening the entry requirements for LEZs and extending LEZs to cover a wider area. Moreover, rather than banning diesel vehicles completely, a ban could be imposed on older vehicle models [15,56] as implemented in Hamburg [62], or diesel vehicles could be banned from entering certain roads that are severely affected by air pollution [63]. This might encourage those who said they "might" buy a diesel vehicle to compromise in the light of the aforementioned types of policy changes.

The KWT was used to ascertain if there was a relationship between the information provision about the harm caused by diesel vehicles and the likelihood of people supporting the ban. The results showed a significant relationship between those two factors with an $\mathrm{H}$-value of 30.38 , as can be seen in Table 2. 
Table 2. Kruskal-Wallis $\mathrm{H}$ test results.

\begin{tabular}{lcc}
\hline \multicolumn{2}{c}{ Category } & \multicolumn{2}{c}{ H Value } \\
\hline & Supporting Ban & Influence on Kind of Vehicle to Buy \\
\hline $\begin{array}{c}\text { Providing information about the } \\
\text { harm caused by vehicle emissions }\end{array}$ & $30.38^{* * *}$ & $11.33^{*}$ \\
Likelihood of switching to EVs & $13.03^{*}$ & - \\
\hline \multicolumn{2}{c}{ Notes: $\mathrm{n}=139 ;{ }^{*} p<0.05^{* *} p<0.01,{ }^{* * *} p<0.001}$.
\end{tabular}

Notes: $\mathrm{n}=139 ;{ }^{*} p<0.05,{ }^{* *} p<0.01, * * * p<0.001$.

In the survey, prior to asking the participants whether they would purchase a diesel vehicle, they were given information about the potential harm caused by such vehicles. This led more than half of them to state that they would not buy a diesel vehicle, as opposed to only $9 \%$ who said they would still buy one. An important implication can be drawn from this, which is that the more awareness people have, the more likely they are to support the ban. This view is also supported by the testimony of Londoners in the survey:

"I was not aware of any damage that diesel vehicles can cause. But luckily with this survey, I am more aware now and will do what I can daily to save the society." (male, 31).

"I believe that what the government is doing is a good step forward. I have a diesel Mercedes CLS, and I really enjoy driving it, but now I am in the process of selling it for the sake of air quality. Thank you." (male, 25).

A key policy priority should, therefore, comprise a strategy to increase the public awareness about the negative health and environmental impacts caused by diesel vehicles emissions. This would facilitate the movement towards a zero-carbon transport system since it is argued that the decarbonisation of the road transport is strongly linked to people's travel behaviour [11].

\subsection{Banning Diesel Vehicles}

Perhaps, surprisingly, analysis of the survey results revealed that the vast majority of respondents would support the ban. About $65 \%$ of the sample population agreed with it, as opposed to $20 \%$ who would not be in favour. Nearly $15 \%$ of the sample population said they "neither agree nor disagree" with the ban, which suggests that they might be open to new policies and would not be considered problematic or non-compliant should such a policy come to be enforced.

A selection of the respondents are cited below expressing their views about the ban:

"I have only recently found out how bad diesel cars can be. It is a great initiative to ban them, but the government should give diesel car owners a huge incentive to compensate for the purchase of a new car that meets their requirements." (male, 42)

"Ban diesel cars, educate people to shift from cars to public transport, and increase diesel prices" (female, 36)

"Getting rid of diesel is just a start, we should work towards banning all private cars as soon as possible, including electrics which waste as much space." (female, 28)

"I would support more punitive measures including the expansion of the Congestion Charge Zone/London LEZ and even higher costs for diesel engines in Parking Control Zones. Also, a London based scrappage scheme which should incentivise diesel car users with active travel-based solutions, e.g., trading your diesel car for a new bike/public transport season ticket etc." (male, 37).

Of those surveyed, almost $13 \%$ advocated the ban when asked about recommendations for improving air quality in London in the open survey question. Therefore, support for a policy enforcing a ban is a conclusion that can legitimately be drawn from the data analysed in this research.

It is believed that banning diesel vehicles would create a positive impact on the environment by reducing the amount of air pollutants in the atmosphere. In Delhi, for example, slightly less than half of the diesel vehicles were replaced by compressed natural gas (CNG) alternatives [59]. Interestingly, in just one year, ambient air pollutants were reduced significantly. The case study reported reductions in sulphur dioxide $\left(\mathrm{SO}_{2}\right)$, carbon monoxide $(\mathrm{CO})$, and $\mathrm{NO}_{\mathrm{x}}$ by $22 \%, 10 \%$, and $6 \%$, 
respectively [59]. We can speculate about what the impact would have been if those diesel vehicles were replaced by zero emission EVs. Likewise, in the context of London, if a total ban on diesel vehicles is implemented, a positive impact would be seen in terms of reductions in pollutant concentrations, similar to, or possibly better than, those reported in the Delhi case study, since they would be replaced by EVs rather than CNG, which represent a more attractive alternative in terms of emissions produced.

Experts argue [7] that banning diesel vehicles would cause a substantial reduction in the $\mathrm{NO}_{\mathrm{x}}$ and $\mathrm{PM}_{2.5}$ emissions of $47 \%$ and $52 \%$, respectively on the 2015 levels by the year 2030. Reductions in the $\mathrm{NO}_{\mathrm{x}}$ and $\mathrm{PM}_{2.5}$ levels would contribute to savings totalling 300 Disability Adjusted Life Years (DALYs). One DALY can be defined as the loss of the equivalent of one year of full health [64]. By the year 2024, diesel vehicles would be responsible for about 6300 DALYs. In the light of these findings, we can claim with confidence, that mitigation measures, i.e., banning diesel vehicles, should be considered as soon as possible. It is further argued that the ban would not only improve air quality and people's health but would also increase the uptake of EVs, especially if the appropriate infrastructure is in place [7].

Although some scholars [16] claim that there is little point in banning individual vehicles from certain roads because doing so would only improve air quality on those particular roads, but could consequently displace the pollution onto other roads, it can be argued that the ban first needs to be tested on specific roads for a certain period of time before implementing it across the entire city. People on low incomes who use their vehicles for their daily commute to work would be the group affected most by the ban since they may struggle to purchase newer models. If the ban is proven to achieve the desired outcomes in respect to improved air quality, then those people could be offered incentives to switch to more environmentally-friendly vehicles or, for instance, benefit from reduced public transport fares.

If policymakers also advocate implementing the ban but have concerns regarding the public acceptability, then the policy could be introduced gradually or on a trial basis. For instance, policymakers could initially enforce a ban on the most polluted roads by restricting the entry of diesel vehicles only. They could also enforce a ban in different areas for a limited amount of time, and then if this was found to result in significant reductions in pollutants levels by monitoring progress, the ban could be extended to more areas of London, thereby increasing the public confidence in respect to any proposed ban.

Overall, it is highly desirable to phase-out all old diesel vehicles since they cause higher levels of pollution than newer models $[2,37,56]$. In addition, new buses and taxis operating in London are more environmentally benign and thus should also be considered as an alternative to current diesel-fuelled vehicles $[17,37]$.

\subsection{Type of Vehicle Owned by Participants}

The results of this survey question provide an insight into the proportion of car users in addition to the engine type of their vehicles. As can be seen from the analysis in Figure 2, at least $61 \%$ of the respondents were car users, while $39 \%$ were non-car users. It can be assumed that some respondents were also car users but did not own a car. The following questions were aimed at eliciting whether car drivers would be willing to switch from ICE vehicles to the use of EVs as the 2040 ban would apply to both petrol and diesel vehicles. If the number of car drivers in this survey had been very low, then the survey analysis would be inadequate because car drivers are the targeted group in respect to their attitudes towards the forthcoming ban and their willingness to shift to more environmentally-friendly alternatives. Therefore, as more than $61 \%$ of the respondents were car drivers, the analysis can be considered valid, although it may be desirable to increase the sample size in further research.

In 2016, there were 39\% diesel vehicles, $60 \%$ petrol vehicles and $1.3 \%$ other vehicle types (EVs and hybrids) in Great Britain [3]. These statistics are consistent with, and to some extent similar to, the survey results in terms of the proportion of each vehicle type among the population, which suggests that the survey succeeded in reaching the targeted groups and being representative of the overall population. 


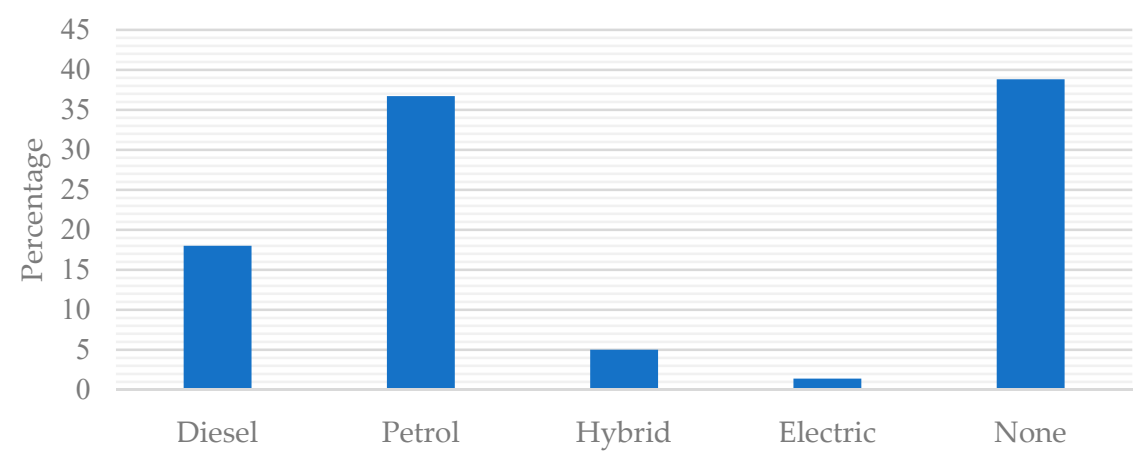

Figure 2. Type of vehicle owned.

\subsection{Shifting to Electric Vehicles}

Remarkably, over $68 \%$ of car drivers said they would agree to replace their current vehicles with EVs, as opposed to $20 \%$ who would refuse. Just under $12 \%$ of the respondents claimed to "neither agree nor disagree" with replacing their vehicles with EVs. It may be possible to persuade this group to switch to EVs by providing scrappage schemes or incentives to purchase them $[37,56]$. Therefore, one implication of this is that the government should provide a scrappage scheme for old vehicles to encourage both those who "disagree" and those who "neither agree nor disagree" to consider this option.

When participants were asked about their recommendations for tackling air pollution, nearly $12 \%$ responded that the adoption of EVs would provide a solution. Furthermore, about $8 \%$ of the participants said that incentives are necessary in order to persuade people to switch to EVs, while others complained about the high prices of EVs. It is therefore proposed that the government and Mayor of London should incentivise the purchase of EVs to increase their uptake rate. Below is a selection of the participants' opinions:

"London's air quality could be improved by the government giving incentives and benefits when people purchase an electric car." (male, 50).

"Diesel cars should be a relic of the past. We need to improve the performance of electric vehicles and lower their cost so that they are more widely adopted." (female, 39).

The KWT was employed to test the relationship between the willingness to switch to EVs and the likelihood of supporting the ban. The results revealed that an $\mathrm{H}$ value of 13.07 was obtained, as highlighted in Table 2, suggesting that a statistically significant relationship exists. As such, those who are willing to replace their diesel/petrol vehicles with electric ones are more likely to support the ban. Therefore, if the Mayor wishes to implement this policy soon, it is advised that the incentives for choosing EVs be put in place [37]. This programme could also be stimulated by the market. For instance, car manufacturers should be encouraged to be ambitious to produce more EVs and fewer ICE ones. After all, as discussed in the analysis, over $68 \%$ of car users agree on the need to shift to EVs.

As stated in the MTS [17], the goal is for all newly registered vehicles in London to be zero emissions so as to achieve the zero-emission road transport by 2050. Therefore, it is vital to discuss which factors would influence the acceptance of EVs in the capital to rapidly increase their adoption as a way to address air pollution.

Fundamentally, moving towards a more sustainable transport system through the uptake of EVs is critically linked to the level of public awareness and concern about the environmental impacts of ICE vehicles as well as EVs. For instance, Khaola et al. [65] investigated a possible correlation between people's concern for the environment and their attitudes towards green products (e.g., EVs) in general and found that there is a strong correlation between them. Additionally, Dogan and Ozmen [66] surveyed 752 respondents to investigate how the environmental concern would affect participants' attitudes towards buying EVs, and they discovered that participants with higher levels of environmental concern were more interested in EVs and more likely to purchase them. 
Furthermore, it is argued that those who seek additional knowledge about EVs may be strongly influenced in terms of positive attitudes towards EVs. Many authors argue $[20,67]$ that having a prior knowledge about EVs can make a huge difference regarding the decision-making process of buying EVs compared to those who have little or no knowledge.

Another factor that is believed to influence the adoption of EVs is incentives [68]. Studies show that providing incentives exerts a positive influence on purchasing EVs $[69,70]$ given that the higher the incentive, the more likely people will purchase an EV. Incentives can be provided in different forms such as tax rebates and subsidies on purchase [71]. A tax rebate of $£ 1000$, for example, means that individuals will have a $£ 1000$ reduction in their tax when they purchase an EV. A study that was conducted in the United States showed that $\$ 1000$ in tax rebate resulted in a $2.6 \%$ increase in EVs sales [71]. It is suggested that a similar method be used in London to encourage more people to purchase zero emission vehicles as an alternative to more polluting ones.

Although EVs are being introduced as an alternative to break fuel dependence and tackle other environmental problems [67], it is imperative to acknowledge that non-exhaust emissions should be also be taken into account when considering how best to address air pollution. There is a substantial volume of literature that has reached the conclusion that the volume of emissions from non-exhaust sources is much greater than emissions from vehicles exhausts [12,72,73]. Therefore, the goal of zero-emission road transport cited in the MTS is most likely to be achieved when there is almost no car use. Otherwise, it would be very challenging to realise this ambitious vision set out by the Mayor in the event that private cars, taxis, and buses continue to operate on London's roads. However, the phasing-out of ICE vehicles would significantly improve the $\mathrm{NO}_{\mathrm{x}}$ reductions [7] since EVs do not emit those kinds of pollutants.

\subsection{Influence on which Kind of Vehicle to Purchase}

The findings from Figure 3 highlight the importance of providing information (i.e., raising awareness) about the harm caused by diesel vehicles, as the participants showed positive attitudes towards low emission vehicles such as hybrids and EVs. Interestingly, about $60 \%$ of those surveyed said that they would purchase a low-emission vehicle including hybrids and EVs. Furthermore, about $4 \%$ of the respondents stated that they would not purchase any vehicle because they prefer to use other types of public transport such as trains, buses, and cycling. In addition, the most remarkable observation to emerge from comparing Figures 2 and 3 is that the percentages of diesel and petrol vehicles dropped by more than half, from $18 \%$ to $8 \%$ and from $37 \%$ to $17 \%$, respectively.

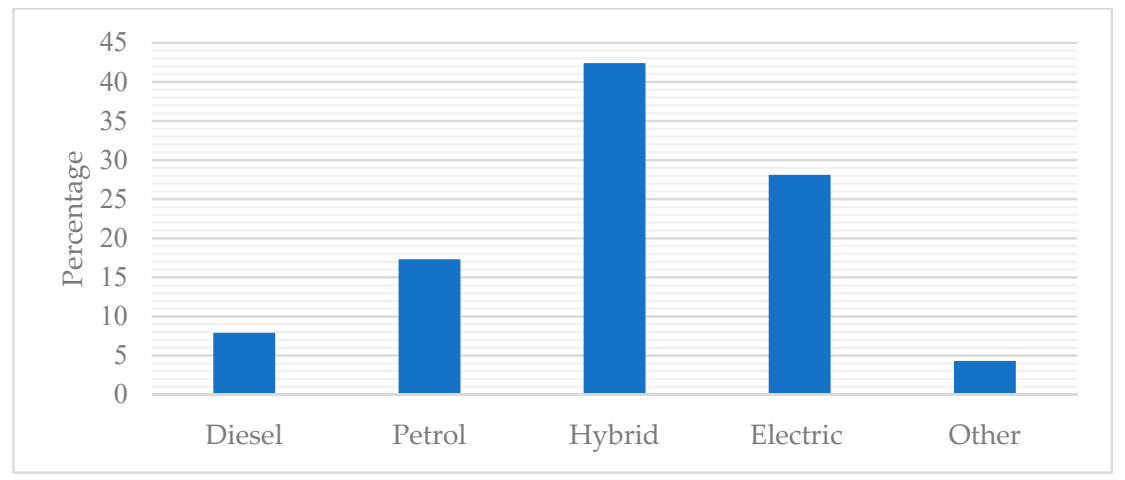

Figure 3. Which kind of vehicle to purchase in the future.

The KWT was also employed here to ascertain the effect of providing information on people's decision-making when buying a new vehicle. The test results presented in Table 1 reveal that providing people with relevant information about the potential harm caused by emissions from diesel vehicles will influence their decision-making process and, ultimately, lead them to make more environmentally friendly choices. It might be argued that those who are considering purchasing a more environmentally 
friendly vehicle are more likely to agree with the ban on diesel vehicles. Therefore, it is essential that the motor industries get involved [37] with this movement towards a sustainable zero-carbon road transport system by providing more environmentally friendly vehicles to help more people to make the shift away from ICE vehicles. This view was also expressed by one survey respondent:

"I think the car industry needs to be the leader. Technology can be used to assist in sustainable \& cost-effective vehicles and transport modes." (female, 29).

Below is a selection of the participants' views about, and recommendations for, improving the local air quality in London:

"Air quality could be improved by creating more green spaces and trees as well as encouraging people to use public transport. Electric vehicles are the future, but at the moment they do not seem to be viable on a large scale due to their high cost." (male, 25).

"Encourage people to use environmentally friendly vehicles by reducing their price." (male, 19).

Although the findings in Figure 3 indicate positive attitudes towards different types of EVs, many researchers [74-76] believe that the high cost of purchase represents a barrier to the adoption of EVs, which concurs with the views cited above. Additionally, several authors $[67,68]$ have identified other potential barriers to the adoption of EVs, such as their limited range, as well as style, size, performance and safety.

Nonetheless, some of these barriers could potentially be overcome by driver training, for example to address the problem of EV's limited mileage range [67]. Moreover, it is important to understand the specific needs and requirements of Londoners in relation to a vehicle. This could help to develop effective policies and stepping-stone guidelines for car manufacturers so as to overcome some of the aforementioned barriers. Two key factors could foster the acceptance of EVs, namely providing incentives in different forms, and raising consciousness about and concern for the environment through awareness campaigns. Acceptance can also be increased by advertising and marketing, which might include word-of-mouth recommendation [77]. Additionally, Globisch et al. [78] stressed the importance of providing EV users with the necessary information, support and assistance to overcome technical failures, as a way to foster the EV deployment. They also found that focusing on the vehicle design (perceived enjoyment) of EVs can significantly influence the choice of the car purchased.

Intervention by policymakers could also make a difference [79]. For instance, a new policy could be introduced stipulating that, for every sports car sold by manufacturers, five EVs should be sold. This would even-out the total amount of emissions produced by a particular car manufacturer since sports cars emit more pollutants than EVs [80]. It would also potentially encourage car manufacturers to set ambitious goals in terms of increasing the EV sales using different methods such as awareness-raising campaigns, and more efficient marketing tools, as well as providing customised assistance to their users.

\section{Conclusions and Policy Implications}

Using London as a case study, this paper explored the public opinion and respondents' views regarding the forthcoming ban on diesel vehicles, examined whether the ban could be implemented earlier than 2040, and set out to discover Londoners' attitudes towards switching to EVs.

The analysis from the KWT revealed that being concerned about the environment, together with an appropriate level of awareness surrounding its vulnerability to certain hazards, could play a huge role in supporting the ban. In order to facilitate the implementation of the ban, it is highly recommended that Londoners' level of awareness about the harm caused by diesel vehicles needs to be increased, which can be achieved by awareness-raising campaigns. Findings from the survey also revealed that the majority of participants "agree" with the ban, suggesting that the policy can be implemented well before 2040. These results have been very encouraging, and the discussion proposed several courses of action for the policy of banning diesel vehicles.

This work has shown substantial evidence that the majority of car drivers-slightly less than $70 \%$-would agree to switch from driving ICE vehicles to EVs. However, some participants raised concerns about the high price of EVs whereas others proposed that the government should provide 
incentives for people to switch to EVs, which suggests that Londoners may not be willing to pay more for a private transport. A further important implication is that Londoners must be provided with incentives tailored to their needs, as well as ways of increasing their awareness of and concern for the environment as a solution to facilitate the acceptance of EVs. Another factor likely to enhance the EV policy and uptake rate is the banning of diesel vehicles, if the appropriate infrastructure is provided. This may include creating sufficient charging stations and extending the installation of charging points to cover more residential areas as well as carparks $[20,67,81]$.

Our findings will be useful for the Mayor of London and policymakers to push the Agenda 2030 forward so as to achieve the goals of sustainable cities and communities as well as climate action [82]. This paper has led us to conclude that the ban should be enforced as soon as possible since the majority of Londoners appear to support the initiative, according to the sample in this research. We would argue that even if $\mathrm{CO}_{2}$ emissions were to be controlled and reduced, the overall climate change effect would still exist because of the time scales involved, meaning that it takes a long time to reverse the severe impacts of poor air quality [18]. In order to achieve the desired outcomes for air quality in the long-term, critical decisions must be taken and "aggressive" policies implemented now to determine the quality of London's air in the future.

Author Contributions: M.S. primarily ran the modelling, produced the figures and tables, designed the questionnaire, collected the surveys, and co-wrote the manuscript. M.C. designed the questionnaire, further interpreted the modelling results, commented on the interview results, and edited the manuscript. Y.Z., C.P., X.G., and Y.L. commented on and edited the manuscript.

Funding: This research received no external funding.

Acknowledgments: The authors would like to thank the two special issue editors and the three anonymous reviewers for their suggestions regarding the improvement of the initial draft. This research did not receive any specific grant from funding agencies in the public, commercial, or not-for-profit sectors.

Conflicts of Interest: The authors declare no conflict of interest.

\section{Abbreviations and Acronyms}

$\begin{array}{ll}\mathrm{CO}_{2} & \text { Carbon Dioxide } \\ \mathrm{NO}_{\mathrm{x}} & \text { Nitrogen Oxides } \\ \mathrm{PM} & \text { Particulate Matter } \\ \mathrm{GHG} & \text { Greenhouse Gas } \\ \mathrm{MTS} & \text { Mayor's Transport Strategy } \\ \text { LEZs } & \text { Low Emission Zones } \\ \mathrm{EVs} & \text { Electric Vehicles } \\ \mathrm{ICE} & \text { Internal Combustion Engine } \\ \mathrm{N} & \text { Total Sample Size } \\ \mathrm{K} & \text { Number of Samples } \\ R_{i} & \text { Sum of Ranks in the } i \text { th Sample } \\ n_{i} & \text { Size of the } i \text { th Sample } \\ \mathrm{KWT} & \text { Kruskal-Wallis Test } \\ \mathrm{CNG} & \text { Compressed Natural Gas } \\ \mathrm{SO} & \text { Sulphur Dioxide } \\ \mathrm{CO} & \text { Carbon Monoxide } \\ \mathrm{DALYs} & \text { Disability Adjusted Life Years }\end{array}$

\section{References}

1. European Commission. Commission and ACEA Agree on $\mathrm{CO}_{2}$ Emissions from Cars. Available online: http://europa.eu/rapid/press-release_IP-98-734_en.htm?locale=en (accessed on 16 July 2019).

2. Laybourn-Langton, L.; Quilter-Pinner, H.; Ho, H. Lethal and Illegal: London's Air Pollution Crisis; Institute for Public Policy Research: London, UK, 2016; Available online: https://www.ippr.org/research/publications/ lethal-and-illegal-londons-air-pollution-crisis (accessed on 26 July 2019). 
3. Department for Transport. Transport Statistics Great Britain 2017; Department for Transport: London, UK, 2017. Available online: https://www.gov.uk/government/statistics/transport-statistics-great-britain-2017 (accessed on 16 July 2019).

4. Turcksin, L.; Mairesse, O.; Macharis, C.; Mierlo, J.V. Encouraging environmentally friendlier cars via fiscal measures: General methodology and application to Belgium. Energies 2013, 6, 471-491. [CrossRef]

5. Sullivan, J.L.; Baker, R.E.; Boyer, B.A.; Hammerle, R.H.; Kenney, T.E.; Muniz, L.; Wallington, T.J. CO 2 emission benefit of diesel (versus Gasoline) powered vehicles. Environ. Sci. Technol. 2004, 38, 3217-3223. [CrossRef] [PubMed]

6. Helmers, E.; Leitão, J.; Tietge, U.; Butler, T. $\mathrm{CO}_{2}$-equivalent emissions from European passenger vehicles in the years 1995-2015 based on real-world use: Assessing the climate benefit of the European "diesel boom". Atmos. Environ. 2019, 198, 122-132. [CrossRef]

7. Dey, S.; Caulfield, B.; Ghosh, B. Potential health and economic benefits of banning diesel traffic in Dublin, Ireland. J. Transp. Health 2018, 10, 156-166. [CrossRef]

8. Andrés, L.; Padilla, E. Driving factors of GHG emissions in the EU transport activity. Transp. Policy 2018, 61, 60-74. [CrossRef]

9. Seo, J.; Park, J.; Oh, Y.; Park, S. Estimation of total transport $\mathrm{CO}_{2}$ emissions generated by medium-and heavy-duty vehicles (MHDVs) in a sector of Korea. Energies 2016, 9, 638. [CrossRef]

10. Santos, G. Road transport and $\mathrm{CO}_{2}$ emissions: What are the challenges? Transp. Policy 2017, 59, 71-74. [CrossRef]

11. Vallack, H.; Haq, G.; Whitelegg, J.; Cambridge, H. Policy pathways towards achieving a zero-carbon transport sector in the UK in 2050. World Transp. Policy Pract. 2014, 20, 28-42.

12. Keuken, M.P.; Moerman, M.; Voogt, M.; Blom, M.; Weijers, E.P.; Röckmann, T.; Dusek, U. Source contributions to PM2.5 and PM10 at an urban background and a street location. Atmos. Environ. 2013, 71, 26-35. [CrossRef]

13. Greater London Authority. Comparison of Air Quality in London with a Number of World and European Cities; Greater London Authority: London, UK, 2014. Available online: https://www.london.gov.uk/sites/default/ files/comparison_of_air_quality_in_world_cities_study_final.pdf (accessed on 16 July 2019).

14. European Commission. Air Quality: Commission Sends Final Warning to the UK Over Levels of Fine Particle Pollution; European Commission: Brussels, Belgium, 2010. Available online: https://europa.eu/rapid/pressrelease_IP-10-687_en.htm (accessed on 15 July 2019).

15. Brand, C. Beyond 'Dieselgate': Implications of unaccounted and future air pollutant emissions and energy use for cars in the United Kingdom. Energy Policy 2016, 97, 1-12. [CrossRef]

16. London Councils. 2018 Air Quality Polling. Available online: https://www.londoncouncils.gov.uk/our-keythemes/environment/air-quality-london/air-quality-public-polling/2018-air-quality-polling (accessed on 26 August 2019).

17. Greater London Authority. The Mayor's Transport Strategy; Greater London Authority: London, UK, 2018. Available online: https://www.london.gov.uk/what-we-do/transport/our-vision-transport/mayors-transportstrategy-2018 (accessed on 16 July 2019).

18. The UK Government's Approach to Delivering the Global Goals for Sustainable Development-At Home and Around the World. Available online: https:/assets.publishing.service.gov.uk/government/uploads/ system/uploads/attachment_data/file/603500/Agenda-2030-Report4.pdf (accessed on 12 August 2019).

19. UK Plan for Tackling Roadside Nitrogen Dioxide Concentrations: An Overview. Available online: https://assets.publishing.service.gov.uk/government/uploads/system/uploads/attachment_data/file/ 633269/air-quality-plan-overview.pdf (accessed on 16 July 2019).

20. Bennett, R.; Vijaygopal, R. An assessment of UK drivers' attitudes regarding the forthcoming ban on the sale of petrol and diesel vehicles. Transp. Res. Part D Transp. Environ. 2018, 62, 330-344. [CrossRef]

21. Meyer, D. Germany's First Diesel Vehicle Ban Has Started in Hamburg. Available online: https://fortune. com/2018/05/31/germany-hamburg-diesel-ban/ (accessed on 16 July 2019).

22. Möhner, M. Driving ban for diesel-powered vehicles in major cities: An appropriate penalty for exceeding the limit value for nitrogen dioxide? Int. Arch. Occup Environ. Health 2018, 91, 373-376. [CrossRef]

23. O'Neill, E.; Moore, D.; Kelleher, L.; Brereton, F. Barriers to electric vehicle uptake in Ireland: Perspectives of car-dealers and policy-makers. Case Stud. Transp. Policy 2019, 7, 118-127. [CrossRef]

24. Ellison, R.B.; Greaves, S.P.; Hensher, D.A. Five years of London's low emission zone: Effects on vehicle fleet composition and air quality. Transp. Res. Part D Transp. Environ. 2013, 23, 25-33. [CrossRef] 
25. Ferreira, F.; Gomes, P.; Tente, H.; Carvalho, A.C.; Pereira, P.; Monjardino, J. Air quality improvements following implementation of Lisbon's Low Emission Zone. Atmos. Environ. 2015, 122, 373-381. [CrossRef]

26. Fensterer, V.; Küchenhoff, H.; Maier, V.; Wichmann, H.-E.; Breitner, S.; Peters, A.; Gu, J.; Cyrys, J. Evaluation of the Impact of Low Emission Zone and Heavy Traffic Ban in Munich (Germany) on the Reduction of PM10 in Ambient Air. Int. J. Environ. Res. Public Health 2014, 11, 5094-5112. [CrossRef] [PubMed]

27. Dastgerdi, A.S.; De Luca, G. Strengthening the city's reputation in the age of cities: An insight in the city branding theory. City Territ. Archit. 2019, 6, 2. [CrossRef]

28. De Jong, M.; Hoppe, T.; Noori, N. City Branding, Sustainable Urban Development and the Rentier State. How do Qatar, Abu Dhabi and Dubai present Themselves in the Age of Post Oil and Global Warming? Energies 2019, 12, 1657. [CrossRef]

29. Greater London Authority. A Growing Population. Available online: https://www.london.gov.uk//what-wedo/planning/london-plan/current-london-plan/london-plan-chapter-one-context-and-strategy-0 (accessed on 16 July 2019).

30. Font, A.; Guiseppin, L.; Blangiardo, M.; Ghersi, V.; Fuller, G.W. A tale of two cities: Is air pollution improving in Paris and London? Environ. Pollut. 2019, 249, 1-12. [CrossRef]

31. Statista. Licensed Cars in London, England 1995-2018. Available online: https://www.statista.com/statistics/ 314980/licensed-cars-in-london-england-united-kingdom/ (accessed on 27 August 2019).

32. Walton, H.; Dajnak, D.; Beevers, S.; Williams, M.; Watkiss, P.; Hunt, A. Understanding the Health Impacts of Air Pollution in London. 2015. Available online: https://www.london.gov.uk/WHAT-WE-DO/environment/ environment-publications/understanding-health-impacts-air-pollution-london (accessed on 15 July 2019).

33. Gordon, I.R.; McCann, P. Innovation, agglomeration, and regional development. J. Econ. Geogr. 2005, 5, 523-543. [CrossRef]

34. Cao, M.; Hickman, R. Car dependence and housing affordability: An emerging social deprivation issue in London? Urban Stud. 2018, 55, 2088-2105. [CrossRef]

35. Davies, A.; MacAulay, S.; DeBarro, T.; Thurston, M. Making Innovation Happen in a Megaproject: London's Crossrail Suburban Railway System. Proj. Manag. J. 2014, 45, 25-37. [CrossRef]

36. Mindell, J.S.; Cohen, J.M.; Watkins, S.; Tyler, N. Synergies between low-carbon and healthy transport policies. Proc. Inst. Civ. Eng. Transp. 2011, 164, 127-139. [CrossRef]

37. Quarmby, S.; Santos, G.; Mathias, M. Air Quality Strategies and Technologies: A Rapid Review of the International Evidence. Sustainability 2019, 11, 2757. [CrossRef]

38. Greater London Authority. London Atmospheric Emissions Inventory (LAEI) 2013-London Datastore. Available online: https://data.london.gov.uk/dataset/london-atmospheric-emissions-inventory-2013 (accessed on 25 July 2019).

39. Valliant, R.; Dever, J.A.; Kreuter, F. Basic steps in weighting. In Practical Tools for Designing and Weighting Survey Samples. Statistics for Social and Behavioral Sciences; Springer: London, UK, 2013.

40. Cao, M. Exploring the Relation between Transport and Social Equity: Empirical Evidence from London and Beijing. Ph.D. Thesis, University College London, London, UK, 2019.

41. Cao, M.; Hickman, R. Urban transport and social inequities in neighbourhoods near underground stations in Greater London. Transp. Plan. Technol. 2019, 42, 419-441. [CrossRef]

42. Cao, M.; Robin, H. Transport, social equity and capabilities in East Beijing. In Handbook on Transport and Urban Transformation in Contemporary China; Chen, C., Pan, H., Shen, Q., Wang, J., Eds.; Edward Elgar: London, UK, 2019.

43. Cao, M.; Hickman, R. Understanding travel and differential capabilities and functionings in Beijing. Transp. Policy 2019. [CrossRef]

44. Capata, R. Urban and extra-urban hybrid vehicles: A technological review. Energies 2018, 11, 2924. [CrossRef]

45. Bamberg, S. How does environmental concern influence specific environmentally related behaviors? A new answer to an old question. J. Environ. Psychol. 2003, 23, 21-32. [CrossRef]

46. Zhao, P.; Li, S.; Li, P.; Liu, J.; Long, K. How does air pollution influence cycling behaviour? Evidence from Beijing. Transp. Res. Part D Transp. Environ. 2018, 63, 826-838. [CrossRef]

47. Zhang, M.; He, S.; Zhao, P. Revisiting inequalities in the commuting burden: Institutional constraints and job-housing relationships in Beijing. J. Transp. Geogr. 2018, 71, 58-71. [CrossRef]

48. Hickman, R.; Cao, M.; Mella Lira, B.; Fillone, A.; Bienvenido Biona, J. Understanding capabilities, functionings and travel in high and low income neighbourhoods in Manila. Soc. Incl. 2017, 5, 161-174. [CrossRef] 
49. Dalgaard, P. Analysis of variance and the Kruskal-Wallis Test. In Introductory Statistics with R; Springer: New York, NY, USA, 2008; pp. 127-143.

50. Leon, A.C. Descriptive and inferential statistics. In Comprehensive Clinical Psychology; Bellack, A.S., Hersen, M., Eds.; Pergamon: Oxford, UK, 1998; pp. 243-285.

51. Martins, F.; Felgueiras, C.; Smitkova, M.; Caetano, N. Analysis of fossil fuel energy consumption and environmental impacts in European Countries. Energies 2019, 12, 964. [CrossRef]

52. Vergura, S. Hypothesis tests-based analysis for anomaly detection in photovoltaic systems in the absence of environmental parameters. Energies 2018, 11, 485. [CrossRef]

53. Zhang, L.; Mu, Z.; Gao, X. Coupling analysis and performance study of commercial 18650 lithium-ion batteries under conditions of temperature and vibration. Energies 2018, 11, 2856. [CrossRef]

54. Siegel, S., Jr.; Castellan, N.J. Nonparametric Statistics for The Behavioral Sciences, 2nd ed.; McGraw-Hill: Boston, MA, USA, 1988; ISBN 978-0-07-057357-4.

55. Fellows, R.; Liu, A. Research Methods for Construction, 4th ed.; Wiley: Chichester, UK; Blackwell: Malden, MA, USA, 2015; ISBN 978-1-118-91572-1.

56. Russell-Jones, R. Air pollution in the UK: Better ways to solve the problem. BMJ 2017, 357, j2713. [CrossRef] [PubMed]

57. MacKerron, G.; Mourato, S. Life satisfaction and air quality in London. Ecol. Econ. 2009, 68, 1441-1453. [CrossRef]

58. Air Quality in Hackney: A Guide for Public Health Professionals. Available online: https://www. london.gov.uk/sites/default/files/air_quality_for_public_health_professionals_-_lb_hackney.pdf (accessed on 15 July 2019).

59. Curtis, C.; Headicar, P. Targeting travel awareness campaigns: Which individuals are more likely to switch from car to other transport for the journey to work? Transp. Policy 1997, 4, 57-65. [CrossRef]

60. Goyal, P. Present scenario of air quality in Delhi: A case study of CNG implementation. Atmos. Environ. 2003, 37, 5423-5431. [CrossRef]

61. Vidhi, R.; Shrivastava, P. A review of electric vehicle lifecycle emissions and policy recommendations to increase EV penetration in India. Energies 2018, 11, 483. [CrossRef]

62. Tietge, U. Cities Driving Diesel Out of the European Car Market. Available online: https://www.fiafoundation. org/media/597008/uwe-tietge.pdf (accessed on 27 July 2019).

63. German Cities Ban Older Diesel Cars. Available online: https://www.reuters.com/article/us-germany-emissionsfactbox/factbox-german-cities-ban-older-diesel-cars-idUSKCN1NK28L (accessed on 27 July 2019).

64. World Health Organization. Disability-Adjusted Life Years (DALYs). Available online: http://www.who.int/ gho/mortality_burden_disease/daly_rates/text/en/ (accessed on 16 July 2019).

65. Khaola, P.P.; Potiane, B.; Mokhethi, M. Environmental concern, attitude towards green products and green purchase intentions of consumers in Lesotho. Ethiop. J. Environ. Stud. Manag. 2014, 7, 361-370. [CrossRef]

66. Dogan, V.; Ozmen, M. Belief in environmentalism and independent/interdependent self-construal as factors predicting interest in and intention to purchase hybrid electric vehicles. Curr. Psychol. 2017. [CrossRef]

67. Rezvani, Z.; Jansson, J.; Bodin, J. Advances in consumer electric vehicle adoption research: A review and research agenda. Transp. Res. Part D Transp. Environ. 2015, 34, 122-136. [CrossRef]

68. Kwon, Y.; Son, S.; Jang, K. Evaluation of incentive policies for electric vehicles: An experimental study on Jeju Island. Transp. Res. Part A Policy Pract. 2018, 116, 404-412. [CrossRef]

69. Krupa, J.S.; Rizzo, D.M.; Eppstein, M.J.; Brad Lanute, D.; Gaalema, D.E.; Lakkaraju, K.; Warrender, C.E. Analysis of a consumer survey on plug-in hybrid electric vehicles. Transp. Res. Part A Policy Pract. 2014, 64, 14-31. [CrossRef]

70. Zhang, Y.; Yu, Y.; Zou, B. Analyzing public awareness and acceptance of alternative fuel vehicles in China: The case of EV. Energy Policy 2011, 39, 7015-7024. [CrossRef]

71. Jenn, A.; Springel, K.; Gopal, A.R. Effectiveness of electric vehicle incentives in the United States. Energy Policy 2018, 119, 349-356. [CrossRef]

72. Ketzel, M.; Omstedt, G.; Johansson, C.; Düring, I.; Pohjola, M.; Oettl, D.; Gidhagen, L.; Wåhlin, P.; Lohmeyer, A.; Haakana, M.; et al. Estimation and validation of PM2.5/PM10 exhaust and non-exhaust emission factors for practical street pollution modelling. Atmos. Environ. 2007, 41, 9370-9385. [CrossRef] 
73. Howard, R. Up in the Air: How to Solve London's Air Quality Crisis-Part 1. 2015. Available online: https://Policyexchange.Org.Uk/Publication/Up-In-The-Air-How-To-Solve-Londons-Air-QualityCrisis-Part-1/ (accessed on 15 July 2019).

74. Graham-Rowe, E.; Gardner, B.; Abraham, C.; Skippon, S.; Dittmar, H.; Hutchins, R.; Stannard, J. Mainstream consumers driving plug-in battery-electric and plug-in hybrid electric cars: A qualitative analysis of responses and evaluations. Transp. Res. Part A Policy Pract. 2012, 46, 140-153. [CrossRef]

75. Jensen, A.F.; Cherchi, E.; Mabit, S.L. On the stability of preferences and attitudes before and after experiencing an electric vehicle. Transp. Res. Part D Transp. Environ. 2013, 25, 24-32. [CrossRef]

76. Lieven, T.; Mühlmeier, S.; Henkel, S.; Waller, J.F. Who will buy electric cars? An empirical study in Germany. Transp. Res. Part D Transp. Environ. 2011, 16, 236-243. [CrossRef]

77. Wikström, M.; Hansson, L.; Alvfors, P. Investigating barriers for plug-in electric vehicle deployment in fleets. Transp. Res. Part D Transp. Environ. 2016, 49, 59-67. [CrossRef]

78. Globisch, J.; Dütschke, E.; Schleich, J. Acceptance of electric passenger cars in commercial fleets. Transp. Res. Part A Policy Pract. 2018, 116, 122-129. [CrossRef]

79. Cao, M.; Chen, C.-L.; Hickman, R. Transport emissions in Beijing: A scenario planning approach. Proc. Inst. Civ. Eng. Transp. 2017, 170, 65-75. [CrossRef]

80. Hooftman, N.; Messagie, M.; Van Mierlo, J.; Coosemans, T. A review of the European passenger car regulations-Real driving emissions vs local air quality. Renew. Sustain. Energy Rev. 2018, 86, 1-21. [CrossRef]

81. Egbue, O.; Long, S. Barriers to widespread adoption of electric vehicles: An analysis of consumer attitudes and perceptions. Energy Policy 2012, 48, 717-729. [CrossRef]

82. Contribution of Working Group I to the Fourth Assessment Report of the Intergovernmental Panel on Climate Change. Available online: https://www.ipcc.ch/site/assets/uploads/2018/02/ar4_syr_full_report.pdf (accessed on 12 August 2019).

(C) 2019 by the authors. Licensee MDPI, Basel, Switzerland. This article is an open access article distributed under the terms and conditions of the Creative Commons Attribution (CC BY) license (http://creativecommons.org/licenses/by/4.0/). 